\title{
Chemical composition and antibacterial activity of the essential oils from the medicinal plant Mentha cervina L. grown in Portugal
}

\author{
Leandra Rodrigues • Aida Duarte • Ana Cristina Figueiredo • Luísa Brito • \\ Generosa Teixeira $\cdot$ Margarida Moldão $\cdot$ Ana Monteiro
}

Received: 17 March 2011/Accepted: 31 October 2011/Published online: 20 November 2011

(C) Springer Science+Business Media, LLC 2011

\begin{abstract}
Mentha cervina is a medicinal plant traditionally used in Portugal in folk medicine, in different gastric disorders and inflammations of the respiratory tract. In order to validate those traditional uses, M. cervina essential oils (EOs) were characterized by GC and GC-MS and their antimicrobial activity was tested against 23 bacterial strains (including multiresistant strains). The EOs were dominated by the monoterpenes pulegone $(52-75 \%)$, isomenthone $(8-24 \%)$, limonene $(4-6 \%)$, and menthone $(1-2 \%)$. The antibacterial activity of these EOs was compared to that of the main components standards. The most effective antibacterial activity was expressed by the EOs against the Gram-negative bacteria, Escherichia coli and Acinetobacter baumanni, with MIC values of $1 \mathrm{mg} / \mathrm{ml}$. The EOs
\end{abstract}

L. Rodrigues $(\varangle) \cdot$ L. Brito $\cdot$ A. Monteiro

Centro de Botânica Aplicada à Agricultura, Instituto Superior de Agronomia, Technical University of Lisbon, Tapada da Ajuda, 1349-017 Lisbon, Portugal

e-mail: liarodrigues@isa.utl.pt

A. Duarte

iMed.UL Faculdade de Farmácia, Universidade de Lisboa,

Avenida Prof. Gama Pinto, 1649-003 Lisbon, Portugal

\section{A. C. Figueiredo}

Faculdade de Ciências de Lisboa, Departamento de Biologia Vegetal, IBB, Centro de Biotecnologia Vegetal, Universidade de Lisboa, C2, Piso 1, Campo Grande, 1749-016 Lisbon, Portugal

\section{G. Teixeira}

Faculdade de Farmácia, Centro de Biologia Ambiental, Universidade de Lisboa, Avenida Prof. Gama Pinto, 1649-003 Lisbon, Portugal

\section{Moldão}

Centro de Engenharia dos Biossistemas, Instituto Superior de Agronomia, Technical University of Lisbon, Tapada da Ajuda, 1349-017 Lisbon, Portugal complex mixtures were more active than the individual aromatic components supporting the hypothesis that the EOs antibacterial activity is a function of the synergistic effect of their different aromatic components. These results show the potential role of M. cervina EOs as antibacterial agents and validate the traditional use of this plant.

Keywords Lamiaceae - GC · GC-MS · Essential oils · Monoterpenes - Antimicrobial activity $\cdot$ MIC

\section{Introduction}

Essential oils (EOs) and their components are gaining increasing interest in the food, cosmetic, and pharmaceutical industries, because of their relatively safe status, their wide acceptance by consumers, and their exploitation for potential multi-purpose functional use (Ormancey et al., 2001). In this view, there is an ongoing effort to screen plants medicinally used in different regions of the world, which is the case of plants from the Lamiaceae family that are long know as important sources of EOs bearing plants used in food, perfume, cosmetic, and pharmaceutical industries because of their culinary, fragrance, and antimicrobial properties (Lis-Balchin and Deans, 1997; Ohloff, 1994;). The EOs from Mentha species have been in use since ancient times for the treatment of many digestive tract diseases and in culinary (İşcan et al., 2002), and they are known to have antimicrobial properties (Flamini et al., 1999; Naigre et al., 1996). As such, mints are valuable crops with a substantial importance in the botanical economy and to the pharmaceutical industry. Concerning the antimicrobial properties of mint EOs, several species of Mentha have been studied, in particular Mentha x piperita L. (peppermint) (İşcan et al., 2002; Yadegarinia et al., 
2006), M. suaveolens Ehrh. (Oumzil et al., 2002), $M$. rotundifolia (L.) Hudson (Derwich et al., 2010), M. pulegium L. (Mahboubi and Haghi, 2008 and citations there in), M. aquatica L. and M. longifolia (L.) Hudson (Gulluce et al., 2007; Mimica-Dukic et al., 2003). These studies yielded results that are difficult to compare, mainly due to the great variation found in the chemical composition of mint EOs and to a lesser extent to differences in the experimental techniques applied. Different Mentha species show differences in their pattern of oil composition, which are the result of their specific metabolic pathways (McConkey et al., 2000). Also, the same taxon growing in different areas may have widely differing chemical components resulting in the existence of intraspecific chemical differences (chemotypes), which is very common in the Mentha genus (Kokkini, 1991). Biological activity, which is dependent on the chemical composition, is similarly subject to variation, explaining the conflicting results concerning their biological properties (Oumzil et al., 2002).

Mentha cervina L., commonly known as hart's pennyroyal, is an aromatic plant traditionally used in Portugal to flavor recipes and in folk medicine, where it is used as an infusion, preventing different gastric disorders and inflammations of the respiratory tract (Monteiro et al., 2007; Póvoa et al., 2006; Rodrigues et al., 2008). This plant is native of the Iberian Peninsula and North Africa, and in Portugal it can be found in streams, bogs and humid places, that are representative of the priority habitat Natura 3170 "temporary Mediterranean ponds" (Silva et al., 2009). The unfavorable conservation status of this habitat, the excessive harvesting for consumption and overgrazing are leading to the disappearance of this species from natural settings (Póvoa et al., 2006).

In a previous study, the $M$. cervina EOs extracted from cultivated populations, were characterized as belonging to the same chemotype-the pulegone chemotype (Rodrigues et al., 2008). Considering the bioactivity of $M$. cervina EOs, there is only one study reporting the antifungal activity against Candida, Aspergillus, and dermatophyte strains (Gonçalves et al., 2007). These authors suggest that $M$. cervina EOs can be used as alternative antifungal agents in the treatment of dermatophytosis. Nevertheless, studies on the antibacterial activities of these EOs are missing.

Given the lack of knowledge on the antibacterial activity of the EOs from $M$. cervina grown in Portugal, the antibacterial capacity of three $M$. cervina EOs was tested against 23 bacterial strains, some of them responsible for digestive and respiratory human diseases and including multiresistant strains. The antibacterial activity of standards from the three main oxygen-containing monoterpenes from the EOs was evaluated. To our knowledge, this is the first report on the antibacterial activity of $M$. cervina EOs from Portuguese populations.

\section{Methods and materials}

Plant material

This study was based on three populations of $M$. cervina collected from natural habitats and kept under culture in the essay field of the Instituto Superior de Agronomia (Lisbon). Voucher specimens from the 3 populations have been deposited in the LISI herbarium under the voucher numbers 532/2005 (MC1), 523/2005 (MC2), and 520/2005 (MC3).

Essential oil isolation procedure

For each EO sample, $20 \mathrm{~g}$ of full flowering aerial parts were subjected to hydro distillation for $1 \mathrm{~h}$ in a Clevengertype apparatus according to the European Pharmacopoeia method (Council of Europe, 2007). The EOs were stored at $-20^{\circ} \mathrm{C}$ in the dark until analysis.

Gas chromatography (GC) and gas chromatographymass spectrometry (GC-MS)

GC and GC-MS analysis were performed according to Rodrigues et al. (2008). The identity of the components was assigned by comparison of their retention indices, relative to a $\mathrm{C}_{9}-\mathrm{C}_{16}$ hydrocarbon standard mixture, and with GC-MS spectra from a home-made library, constructed based on the analyses of reference oils, laboratory-synthesised components and commercial available standards.

\section{Bacterial strains}

Twenty-three bacterial strains were tested most of them pathogenic for humans and showed multiresistance to antibiotics. The Gram-positive strains are: Staphylococcus aureus (ATCC and MRSA-Meticillin resistant S. aureus), S. caprae, Enterococcus faecalis (VRE-Vancomycin resistant Enterococcus), E. faecium, E. hirae, and four Listeria monocytogenes strains. The Gram-negative strains are: Escherichia coli (ATCC and $\beta$-lactamase CTX-M-15 producers), Salmonella braenderup; S. typhimurium; S. choleraesuis, Klebsiella pneumoniae (CIP and extended-spectrum $\beta$-lactamases-ESBL producer), Acinetobacter baumannii (ATCC and multiresistant European clone II strain and the metallo- $\beta$-lactamase IMP-5 producer), Pseudomonas aeruginosa (ATCC and multiresistant strain by efflux pump). The microorganisms were derived from reference cultures (ATCC and CIP) and stock cultures from CBLBFF (Colecção de Bactérias do Laboratório de Bacteriologia da Faculdade de Farmácia) and CBISA (Colecção de Bactérias do Instituto Superior de Agronomia). 
Antimicrobial activity assay

The bacterial strains were challenged with the three different M. cervina EOs and also with pure standards of the three main components of these EOs, menthone, isomenthone, and pulegone (Fluka) in order to evaluate their antimicrobial activities. Since a preliminary control test with the solvent DMSO, in a range of $125-250 \mathrm{mg} / \mathrm{ml}$ yielded no effect on microbial growth, the EOs and the standards were solubilized in this solvent (ratio of 1:1) and then diluted in culture media for use. The minimum inhibitory concentration (MIC) values were determined by the microdilution broth method, as reported in NCCLS (2006). Microdilution broth test was performed in MuellerHinton broth medium, in 96-well micro plates, as follows: $100 \mu \mathrm{l}$ of Mueller-Hinton broth was added into each well of the micro plate and $100 \mu \mathrm{l}$ of each EO or pure standards diluted in DMSO (1:1) were added to the first row of the micro plate and then serially twofold diluted in a final volume of $100 \mu \mathrm{l}$, respectively, with concentrations ranging from 250 to $0.25 \mathrm{mg} / \mathrm{ml}$. The wells were then inoculated with $10 \mu \mathrm{l}$ of each bacterial suspension, adjusted to $0.5 \mathrm{McF}$ arland (about $10^{7}-10^{8} \mathrm{CFU} / \mathrm{ml}$ ). The last row containing the bacterium in Mueller-Hinton broth without the test sample was used as a control for strain viability. Ampicillin and Riphampicin were used as a reference compound for antibacterial activities of Gram-negative and Gram-positive bacteria, respectively. The microplates were covered and incubated for $24 \mathrm{~h}$ at $37^{\circ} \mathrm{C}$. Each experiment was performed in triplicate. The MIC was determined as the lowest concentration of the product inhibiting the growth of the microorganisms.

Interpretation of the results

The interpretation of microbial growth was based on the following criterion: the result was considered positive, thus, presenting microbial growth, when at least two of three replicates presented visible growth. When visible growth was detected only in one or in none of the three replicates, the result was considered negative, thus, indicating absence of microbial growth.

\section{Results and discussion}

Essential oil chemical composition

Thirty-three components were identified in the M. cervina evaluated EOs, covering $88-97 \%$ of the total (Table 1). Oxygen-containing monoterpenes constituted the main fraction in all EOs (80-88\%), pulegone $(52-75 \%)$, isomenthone (8-24\%), limonene (4-6\%), and menthone (1-2\%)
Table 1 Composition of the essential oils isolated by hydrodistillation from the flowering aerial parts of three Mentha cervina cultivated populations

\begin{tabular}{|c|c|c|c|c|}
\hline \multirow[t]{2}{*}{ Components } & \multirow[t]{2}{*}{$\mathrm{RI}^{\mathrm{a}}$} & \multicolumn{3}{|c|}{$\begin{array}{l}\text { Mentha cervina } \\
\text { populations }\end{array}$} \\
\hline & & MC1 & MC2 & MC3 \\
\hline 3-Methyl cyclohexanone & 914 & $\mathrm{t}$ & $\mathrm{t}$ & $\mathrm{t}$ \\
\hline$\alpha$-Thujene & 924 & $\mathrm{t}$ & $\mathrm{t}$ & $\mathrm{t}$ \\
\hline$\alpha$-Pinene & 930 & 0.5 & 0.6 & 0.1 \\
\hline Camphene & 938 & $\mathrm{t}$ & $\mathrm{t}$ & 0.1 \\
\hline Sabinene & 958 & 0.3 & 0.1 & $\mathrm{t}$ \\
\hline 1-Octen-3-ol & 961 & $\mathrm{t}$ & $\mathrm{t}$ & $\mathrm{t}$ \\
\hline$\beta$-Pinene & 963 & 0.2 & 0.8 & 0.2 \\
\hline 2.5-Dimethyl-1-hexene & 970 & $\mathrm{t}$ & $\mathrm{t}$ & $\mathrm{t}$ \\
\hline 3-Octanol & 974 & 1.0 & 0.6 & 2.4 \\
\hline$\beta$-Myrcene & 975 & 0.6 & 0.4 & $\mathrm{t}$ \\
\hline p-Cymene & 1003 & $\mathrm{t}$ & 0.1 & $\mathrm{t}$ \\
\hline 1.8-Cineole & 1005 & 0.3 & 0.3 & 0.1 \\
\hline Limonene & 1009 & 6.1 & 5.6 & 4.0 \\
\hline cis- $\beta$-Ocimene & 1017 & 0.1 & $\mathrm{t}$ & $\mathrm{t}$ \\
\hline trans- $\beta$-Ocimene & 1027 & $\mathrm{t}$ & $\mathrm{t}$ & 0.1 \\
\hline$\gamma$-Terpinene & 1035 & $\mathrm{t}$ & $\mathrm{t}$ & $\mathrm{t}$ \\
\hline$n$-Octanol & 1045 & $\mathrm{t}$ & $\mathrm{t}$ & 0.1 \\
\hline cis-Linalool oxide & 1045 & 0.1 & $\mathrm{t}$ & $\mathrm{t}$ \\
\hline trans-Limonene oxide & 1112 & 0.1 & $\mathrm{t}$ & 0.1 \\
\hline Menthone & 1120 & 0.9 & 2.2 & 1.8 \\
\hline Isomenthone & 1126 & 8.3 & 21.2 & 24.4 \\
\hline Menthofuran & 1134 & $\mathrm{t}$ & $\mathrm{t}$ & $\mathrm{t}$ \\
\hline cis-Isopulegone & 1134 & 1.0 & 0.9 & 1.2 \\
\hline Terpinen-4-ol & 1148 & $\mathrm{t}$ & $\mathrm{t}$ & $\mathrm{t}$ \\
\hline Verbenone & 1164 & $\mathrm{t}$ & $\mathrm{t}$ & $\mathrm{t}$ \\
\hline Myrtenol & 1168 & $\mathrm{t}$ & $\mathrm{t}$ & $\mathrm{t}$ \\
\hline Pulegone & 1210 & 74.9 & 62.7 & 52.2 \\
\hline Piperitone & 1211 & $\mathrm{t}$ & 0.2 & $\mathrm{t}$ \\
\hline Carvotanacetone & 1222 & $\mathrm{t}$ & $\mathrm{t}$ & 0.6 \\
\hline Piperitenone & 1289 & 1.5 & 0.6 & $\mathrm{t}$ \\
\hline$\beta$-Caryophyllene & 1414 & 0.3 & 0.2 & $\mathrm{t}$ \\
\hline$\beta$-Caryophyllene oxide & 1561 & $\mathrm{t}$ & 0.8 & 1.0 \\
\hline Humulene epoxide & 1580 & 0.1 & $\mathrm{t}$ & $\mathrm{t}$ \\
\hline$\%$ Identification & & 96.3 & 97.3 & 88.4 \\
\hline \multicolumn{5}{|l|}{ Grouped components } \\
\hline Monoterpene hydrocarbons & & 7.8 & 7.6 & 4.5 \\
\hline Oxygen-containing monoterpenes & & 87.1 & 88.1 & 80.4 \\
\hline Sesquiterpene hydrocarbons & & 0.3 & 0.2 & $\mathrm{t}$ \\
\hline Oxygen-containing sesquiterpenes & & 0.1 & 0.8 & 1.0 \\
\hline Others & & 1.0 & 0.6 & 2.5 \\
\hline
\end{tabular}

${ }^{a}$ Retention Index relative to $\mathrm{C}_{9}-\mathrm{C}_{16} n$-alkanes on the DB-1 column; $t$ trace $(<0.05)$

being the main components (Table 1). These results are in accordance with previous studies, which have shown high chemical correlation for Portuguese M. cervina EOs 
(Gonçalves et al., 2007; Rodrigues et al., 2008), although some variability was shown in the EOs isolated from this species grown in other countries (Lawrence, 2007). Despite the chemical homogeneity between the evaluated oils, three different profiles were considered, a pulegone-rich with the lowest level of isomenthone (MC1 in Table 1) and two pulegone-rich with similar high levels of isomenthone (MC2 and MC3 in Table 1) but that showed slight differences in the relative amount of the minor EOs components.

Antibacterial activity of the $M$. cervina EOs and of the pure aromatic compounds

The antibacterial capacity of the three different EOs profiles was compared among each other and to standards from the EOs oxygen-containing monoterpene main components, pulegone, isomenthone, and menthone. The results showed that the antibacterial activity of the $M$. cervina EOs and the standard compounds is dependent of the type of microorganisms and in different degrees on the EO profile and the pure aromatic compound used (Table 2).

In general, Gram-negative bacteria were more sensitive than Gram-positive bacteria (Table 2). Gram-negative bacteria showed MIC values of $1 \mathrm{mg} / \mathrm{ml}$, using the complex mixture of EOs. The OEs activity against Gram-positive bacteria was less noteworthy with the lowest MIC values equal or more than $7.8 \mathrm{mg} / \mathrm{ml}$, with exception for $S$. aureus ATCC 6533 that was more susceptible $(2 \mathrm{mg} / \mathrm{ml}$ with MC3). With the pure compounds, we had the same behavior, the Gram-positive showed MIC values equal or more than $62.5 \mathrm{mg} / \mathrm{ml}$ (also with exception for $S$. aureus), and in the Gram-negative bacteria we could find MIC values of $2 \mathrm{mg} / \mathrm{ml}$.

Although it has been established that Gram-positive bacteria are much more sensitive to drug action than Gramnegative bacteria (Cos et al., 2006), because of their less complex membrane structure (Cosentino et al., 1999; Karaman et al., 2003; Sahin et al., 2002), the results presented in this study with $M$. cervina EOs are not in accordance with this. The same results were obtained in other studies using $M$. pulegium and $M$. longifolia EOs (Gulluce et al., 2007; Hajlaoui et al., 2009; Hafedh et al., 2010; Mahboubi and Haghi, 2008). The results obtained in our study are promising because the $M$. cervina EOs could be important in future formulations for treatment of multiresistant Gram-negative pathogens, including Acinetobacter spp., $P$. aeruginosa and, because of their production of extended-spectrum $\beta$-lactamase, Enterobacteriaceae, responsible for serious infections in community and hospital patients (Slama, 2008).

The most considerable antibacterial activity was obtained against $E$. coli and $A$. baumannii, using the EOs complex mixtures. The EO MC2 showed the lowest MIC value of $1 \mathrm{mg} / \mathrm{ml}$ for both $E$. coli strains (ATCC and the multiresistant) and the A. baumannii. Although we can find in the literature studies using mint EOs, the results are difficult to compare because the methodologies and the bacterial strains used are different among studies. Moreover, the same species may also present different chemotypes. For E. coli strains, we could find MIC values of 0.78 and $2.25 \mathrm{mg} / \mathrm{ml}$ using $M$. longifolia EO (Hafedh et al., 2010 and Hajlaoui et al., 2009, respectively), 2.25 and $4 \mathrm{mg} / \mathrm{ml}$ with M. pulegium EO (Hajlaoui et al., 2009 and Mahboubi and Haghi, 2008, respectively), and $250 \mathrm{mg} / \mathrm{mL}$ with $M$. rotundifolia EOs (Derwich et al., 2010). Interestingly the plant species with more pronounced antibacterial activity were the ones presenting EOs with high content in the monoterpenes pulegone, menthone and isomenthone (M. pulegium, M. longifolia, and $M$. cervina in this study).

The antibacterial activity of the EOs was higher (Table 2) when compared with the pure standard compounds. Considering the bioactivity of the pure standards alone, in general, isomenthone and menthone, were less active than pulegone (its precursor), with the exceptions for S. thyphimurium and S. aureus ATCC (Table 2). Similar results were obtained by other authors that reported pulegone as showing a more potent bioactivity (Flamini et al., 1999; Gulluce et al., 2007; Hajlaoui et al., 2008; Naigre et al., 1996; Oumzil et al., 2002; Mimica-Dukic et al., 2003; Oyedeji and Afolayan, 2005). Considering the results with the three EOs profiles, MC3 (the EO with less content in pulegone), was the one who exhibited higher antibacterial activity against all Gram-positive and Gram-negative bacteria (Table 2). In general, the order of efficacy was MC1 < MC2 < MC3, which appears to be related to the decrease in pulegone content. So, although pulegone showed the higher antimicrobial activity (considering the pure standard compounds alone), these results do not agree with the data obtained with the EOs complex mixtures, where the EO with less content in pulegone exhibited the best results. Using $M$. cervina EOs for antifungal activities against Candida, Aspergillus, and dermatophyte strains, Gonçalves et al. (2007) also obtained the highest activity with the sample containing lower amounts of pulegone. The same type of response of EO complex mixtures and individual components was reported in other species, using M. x piperita EO against E. coli, S. aureus, and Candida albicans (Yadegarinia et al., 2006) and with M. spicata EO against L. monocytogenes (Leonard et al., 2010). Given the heterogeneous composition of EOs and the different antimicrobial activities of its components, it seems that different components may have different modes of action and that the activity could be attributed to the presence of minor components or at least to a synergistic effect between components. 
Table 2 Minimum inhibitory concentration (MIC, mg/ml) of M. cervina essential oils, pure standard compounds, and DMSO, against different bacterial strains

\begin{tabular}{|c|c|c|c|c|c|c|c|c|}
\hline \multirow[t]{3}{*}{ Bacteria strains } & \multicolumn{8}{|c|}{ MIC (mg/ml) } \\
\hline & \multicolumn{3}{|c|}{ Essential oils } & \multicolumn{4}{|c|}{ Pure compounds and solvent } & \multirow[t]{2}{*}{ Antibiotics } \\
\hline & MC1 & MC2 & MC3 & Pulegone & Isomenthone & Menthone & DMSO & \\
\hline \multicolumn{9}{|l|}{ GRAM- } \\
\hline \multicolumn{9}{|l|}{ Pseudomonas aeruginosa } \\
\hline ATCC 10554 & 125 & 62.5 & 15.6 & 125 & 125 & 125 & $>250$ & $<0.25$ \\
\hline MR (ID 1833) & 125 & 31.3 & 31.3 & 125 & 125 & 125 & $>250$ & $>250$ \\
\hline \multicolumn{9}{|l|}{ Escherichia coli } \\
\hline ATCC 11105 & 2.0 & 1.0 & 1.0 & 3.9 & 15.6 & 31.3 & 125 & $<0.25$ \\
\hline CTX (ID2511) & 7.8 & 1.0 & 2.0 & 3.9 & 62.5 & 62.5 & 125 & 62.5 \\
\hline \multicolumn{9}{|l|}{ Acinetobacter baumannii } \\
\hline ATCC 19606 & 3.9 & 2.0 & 3.9 & 2.0 & 31.3 & 62.5 & 125 & $<0.25$ \\
\hline MR (ID130) & 2.0 & 1.0 & 1.0 & 2.0 & 15.6 & 15.6 & 125 & 15.6 \\
\hline IMP5 (ID65) & 1.0 & 1.0 & 2.0 & 2.0 & 15.6 & 15.6 & 125 & $<0.25$ \\
\hline \multicolumn{9}{|l|}{ Klebsiella pneumoniae } \\
\hline KPC (ID2564) & 62.5 & 3.9 & 7.8 & 62.5 & 62.5 & 62.5 & 125 & - \\
\hline CTX-M-15 (ID2510) & 31.3 & 7.8 & 15.6 & 62.5 & 125 & 125 & 125 & - \\
\hline TEM-10 (ID683) & 62.5 & 15.6 & 15.6 & 31.3 & 62.5 & 125 & 125 & - \\
\hline \multicolumn{9}{|l|}{ Salmonella thyphimurium } \\
\hline CBISA 3969 & 62.5 & 31.3 & 15.6 & 62.5 & 7.8 & 31.3 & 125 & $<0.25$ \\
\hline \multicolumn{9}{|l|}{ Salmonella braenderup } \\
\hline CBISA 3991 & 31.3 & 31.3 & 7.8 & 31.3 & 62.5 & 62.5 & 125 & $<0.25$ \\
\hline \multicolumn{9}{|l|}{ GRAM+ } \\
\hline \multicolumn{9}{|l|}{ Staphylococcus aureus } \\
\hline ATCC 6533 & 31.3 & 15.6 & 2.0 & 62.5 & 15.6 & 15.6 & $>250$ & $<0.25$ \\
\hline MRSA CIP 106760 & 62.5 & 15.6 & 7.8 & 62.5 & 125 & 125 & $>250$ & - \\
\hline \multicolumn{9}{|l|}{ Staphylococcus caprae } \\
\hline CBISA 3572 & 62.5 & - & 7.8 & 125 & 125 & 125 & $>250$ & $<0.25$ \\
\hline \multicolumn{9}{|l|}{ Enterococcus faecalis } \\
\hline CIP 104476 & 62.5 & 31.3 & 15.6 & 125 & 125 & 125 & $>250$ & 125 \\
\hline \multicolumn{9}{|l|}{ Enterococcus faecium } \\
\hline ID 435628 & 62.5 & 62.5 & 15.6 & 125 & 125 & 125 & $>250$ & 2.0 \\
\hline \multicolumn{9}{|l|}{ Enterococcus hirae } \\
\hline CIP 5855 & 62.5 & 62.5 & 15.6 & 125 & 125 & 125 & $>250$ & 2.0 \\
\hline \multicolumn{9}{|l|}{ Listeria monocytogenes } \\
\hline EGDe (CBISA 3992) & 62.5 & - & 7.8 & 125 & 125 & 125 & 125 & $<0.25$ \\
\hline CECT (CBISA 3004) & 62.5 & - & 7.8 & 125 & 125 & 125 & 125 & $<0.25$ \\
\hline CBISA 3845 & 62.5 & - & 7.8 & 125 & 125 & 125 & 125 & $<0.25$ \\
\hline CBISA 3077 & 125.0 & - & 15.6 & 125 & 125 & 125 & 125 & $<0.25$ \\
\hline
\end{tabular}

${ }^{a}$ Ampicillin and riphampicin were used as reference compounds for antibacterial activities of Gram-negative and Gram-positive bacteria, respectively

\section{Conclusion}

This study demonstrated the potential use of M. cervina EOs as well as their components as antibacterial agents, in particular against Gram-negative bacteria, such as E. coli and A. baumannii, providing an explanation for the reported traditional use of this plant. These results also support the hypothesis that the antibacterial activity of the $M$. cervina EOs is a function of the synergistic effect of their different aromatic monoterpene constituents. The 
extraction of active compounds in single or combined forms, from this plant, may lead to their use as food preservatives as well as in pharmaceutical and natural therapies for the treatment of infectious diseases. Nevertheless, further research is required to evaluate the practical value of M. cervina EOs applications.

Acknowledgment The financial support of Fundação para a Ciência e Tecnologia (FCT/CBAA and PhD Grant SFRH/BD/38143/2007 of Leandra Rodrigues) is gratefully acknowledged.

\section{References}

Cos P, Vlietinck AJ, Berghe DV, Maes L (2006) Anti-infective potential of natural products: how to develop a stronger in vitro 'proof-of-concept'. J Ethnopharmacol 106:290-302

Cosentino S, Tuberoso CIG, Pisano B, Satta M, Mascia V, Arzedi E (1999) In vitro antimicrobial activity and chemical composition of Sardinian Thymus essential oils. Lett Appl Microbiol 29: $130-135$

Council of Europe (COE) (2007) European Directorate for the Quality of Medicines, 6th edn. European Pharmacopoeia, Strasbourg

Derwich E, Benziane Z, Boukir A (2010) Antibacterial activity and chemical composition of the leaf essential oil of Mentha rotundifolia from Marocco. EJEAFChe 9(1):19-28

Flamini G, Cioni PL, Puleio R, Morelli I, Panizzi L (1999) Antimicrobial activity of the essential oil of Calamintha nepeta and its constituent pulegone against bacteria and fungi. Phytother Res 13:349-351

Gonçalves M, Vicente A, Cavaleiro C, Salgueiro L (2007) Composition and antifungal activity of the essential oil of Mentha cervina from Portugal. Nat Prod Res 21(10):867-871

Gulluce M, Sahin F, Sokmen M, Ozer H, Daferera D, Sokmen A, Polissiou M, Adiguzel A, Ozkan H (2007) Antimicrobial and antioxidant properties of the essential oils and methanol extract from Mentha longifolia L. ssp. Longifolia. Food Chem 103:1449-1456

Hafedh H, Fethi BA, Mejdi S, Emira N, Amina B (2010) Effect of Mentha longifolia L. ssp longifolia essential oil on the morphology of four pathogenic bacteria visualized by atomic force microscopy. Afr J Microbiol Res 4(11):1122-1127

Hajlaoui H, Snoussi M, Ben Jannet H, Mighri Z, Bakhrouf A (2008) Comparison of chemical composition and antimicrobial activities of Mentha longifolia L. ssp. longifolia essential oil from two Tunisian localities (Gabes and Sidi Bouzid). Ann Microbiol 58(3): 103-110

Hajlaoui H, Trabelsi N, Noumi E, Snoussi M, Fallah H, Ksouri R, Bakhrouf A (2009) Biological activities of the essential oils and methanol extract of tow cultivated mint species (Mentha longifolia and Mentha pulegium) used in the Tunisian folkloric medicine. World J Microbiol Biotechnol 25:2227-2238

İşcan G, Krmer N, Kürkcüolu M, Hüsnü K, Başer C, Demrc F (2002) Antimicrobial screening of Mentha piperita essential oils. J Agric Food Chem 50(14):3943-3946

Karaman I, Sahin F, Gulluce M, Ogutc H, Sengul M, Adiguzel A (2003) Antimicrobial activity of aqueous and methanol extracts of Juniperus oxycedrus L. J Ethnopharmacol 85:231-235

Kokkini S (1991) In: Liskens HF, Jackson JF (eds) Essential oils and waxes-chemical races within the genus Mentha L. SpringerVerlag, Berlin, pp 63-78
Lawrence BM (2007) The composition from commercially important mints. In: Lawrence BM (ed) Mint. The genus Mentha. CRC Press, Boca Raton, pp 217-323

Leonard CM, Virijevic S, Regnier T, Combrinck S (2010) Bioactivity of selected essential oils and some components on Listeria monocytogenes biofilms. S Afr J Bot 76(4):676-680

Lis-Balchin M, Deans SG (1997) Bioactivity of selected plant essential oils against Listeria monocytogenes. J Appl Bacteriol 82:759-762

Mahboubi A, Haghi G (2008) Antimicrobial activity and chemical composition of Mentha pulegium L. essential oil. J Ethnopharmacol 119(2):325-327

McConkey ME, Gershenzon J, Croteau RB (2000) Developmental regulation of monoterpene biosynthesis in the glandular trichomes of peppermint. Plant Physiol 122:215-223

Mimica-Dukic N, Bozin B, Sokovic M, Mihajlovic B, Matavulj M (2003) Antimicrobial and antioxidant activities of three Mentha species essential oils. Planta Med 69(5):413-419

Monteiro A, Póvoa O, Marinho S, Rodrigues L, Monteiro P (2007) Mentha pulegium e Mentha cervina-Os poejos na boa cozinha portuguesa. ISA press, Lisboa

Naigre R, Kalck P, Roques C, Roux I, Michel G (1996) Comparison of antimicrobial properties of monoterpenes and their carbonylated products. Planta Med 62(3):275-277

NCCLS (2006) National committee for clinical laboratory standards: methods for dilution antimicrobial susceptibility tests for bacteria that grow aerobically, 7th edn. Approved Standard M7-A7, Wayne

Ohloff G (1994) In Scent and Fragrances: The Fascination of Odors and their Chemical Perspectives. Springer-Verlag, New York

Ormancey X, Sisalli S, Coutiere P (2001) Formulation of essential oils in functional perfumery. Parfum Cosmet Actual 157:30-40

Oumzil H, Ghoulami S, Rhajaoui M, Ilidrissi A, Fkih-Tetouani S, Faid M, Benjouad A (2002) Antibacterial and antifungal activity of essential oils of Mentha suaveolens. Phytother Res 16:727731

Oyedeji O, Afolayan A (2005) Comparative study of the essential oil composition and antimicrobial activity of Leonotis leonurus and L. ocymifolia in the Eastern Cape. S Afr J Bot 71:114-116

Póvoa O, Farinha N, Marinho S, Nunes P, Godinho D, Mata F, Rodrigues L, Monteiro A (2006) Pennyroyal (Mentha pulegium) and Hart's Pennyroyal (Mentha cervina) biodiversity in Alentejo, Portugal. Acta Hortic 723:91-97

Rodrigues L, Monteiro $\mathrm{P}$, Póvoa $\mathrm{O}$, Teixeira $\mathrm{G}$, Moldão $\mathrm{M}$, Figueiredo AC, Monteiro A (2008) Morphology of secretory structures and essential oil composition in Mentha cervina L. from Portugal. Flavour Fragr J 23:340-347

Sahin F, Karaman I, Gulluce M, Ogutcu H, Sengul M, Adiguzel A, Ozturk S, Kotana R (2002) Evaluation of antimicrobial activities Satureja hortensis L. J Ethnopharmacol 87:61-65

Silva V, Póvoa O, Espírito-Santo MD, Vasconcelos T, Monteiro A (2009) Mentha cervina communities in Portugal. Lazaroa 30: 73-79

Slama T (2008) Gram-negative antibiotic resistance: there is a price to pay. Crit Care 12(Suppl 4):S4

Yadegarinia D, Gachkar L, Rezaei MB, Taghizadeh M, Astaneh SA, Rasooli I (2006) Biochemical activities of Iranian Mentha piperita L. and Myrtus communis L. essential oils. Phytochemistry 67(12):1249-1255 